\title{
European court clears way for stem-cell patents
}

A ruling from the European Court of Justice lifts 2011 ban on patenting embryonic stem cells made from unfertilized eggs.

Ewen Callaway \& Alison Abbott

18 December 2014

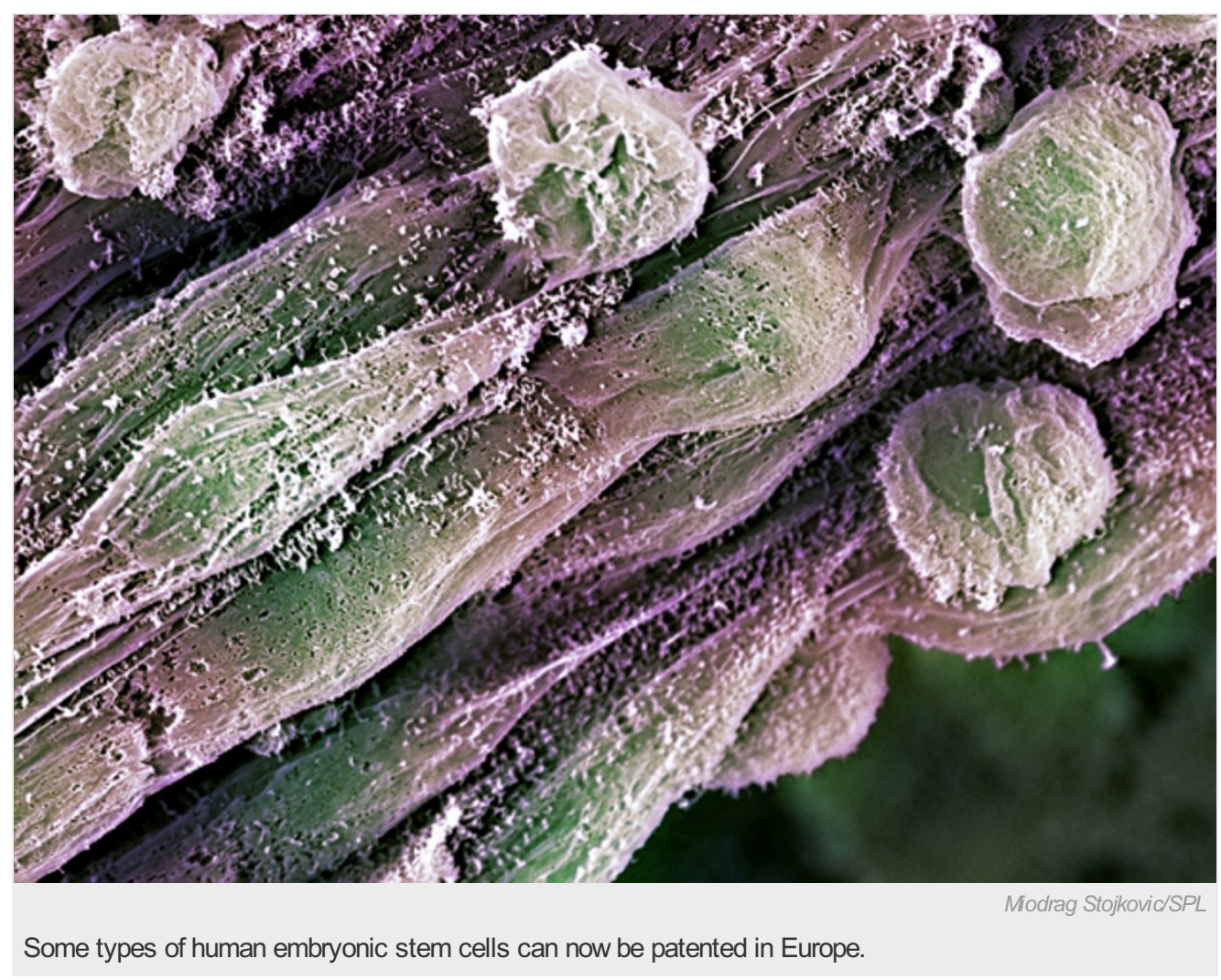

Europe's highest court has ruled that human embryonic stem cells made from unfertilized eggs can be patented — on the basis that they lack the capacity to turn into a human being.

The cells in question are created through a process called parthenogenesis, after the Greek words for virgin and birth. In some animals, parthenogenesis is a means of asexual reproduction, but human cells created in this way do not develop properly.

The ruling, issued on 18 December by the European Court of Justice, backtracks on the court's more general 2011 ban on obtaining patents for human embryonic stem (ES) cells.

The ban had come in response to a patent sought by stem-cell scientist Oliver Brüstle of the University of Bonn, Germany, for a process of 
making neurons from ES cells. As well as banning patents that involve the destruction of cells capable of forming human embryos, the court forbade patents on ES cells made from 'parthenote' eggs, stating that they are capable of "commencing the process of development of a human being".

But many scientists denounced the decision, arguing that it would slow down the development of cellbased therapies. "We have known for a very long time that parthenogenetic (or parthenote) embryos are not capable of developing very far after implantation", says Robin Lovell-Badge, a stem-cell scientist at the National Institute for Medical Research in London.

\section{'Generally good news'}

International Stem Cell Corporation, a biotechnology company in Carlsbad, California, challenged the judgement after an application it made in the United Kingdom for two patents was rejected. The patents covered methods to generate corneal tissue from ES cells that had been made from egg cells, or ova, through parthenogenesis.

In a press release, the European court said: "The mere fact that a parthenogenetically-activated human ovum commences a process of development is not sufficient for it to be regarded as a human embryo." It is now up to the UK courts to decide whether the cells generated by International Stem Cell Corporation qualify for patent protection.

Julian Hitchcock, a biotechnology lawyer at Lawford Davies Denoon in London, says that the court's decision raises questions about the advice that underpinned the 2011 findings. The ruling could spur further challenges to the patent ban, he adds.

The ruling "is generally good news", says Clara Sattler de Sousa e Brito, lawyer based in Munich, Germany, who represented Brüstle. "It opens a clear space to argue some other methods, like somatic nuclear transfer (also known as cloning), create sources of human embryonic stem cells that do not have the capability of develop into a human being — and should thus also be patentable."

But she adds that it would be harder to argue scientifically that the most common source of human embryonic stem cells — spare human embryos - do not have this capability.

Nature I doi:10.1038/nature.2014.16610

\section{SPRINGER NATURE}

